\title{
Contribution of Gender, Marital Status, and Age to English Language Teachers' Burnout
}

\author{
Seyedehhava Mousavy \\ Faculty of Educational Sciences, Universiti Putra Malaysia \\ E-mail: saharmsv333@gmail.com \\ Vahid Nimehchisalem (Corresponding Author) \\ English Language Department, Faculty of Modern Languages and Communication, Universiti Putra Malaysia, Serdang 43400, Selangor, Malaysia \\ E-mails:vahid@upm.edu.my; nimechie@gmail.com
}

Doi:10.7575/aiac.alls.v.5n.6p.39

Received: 08/08/2014

URL: http://dx.doi.org/10.7575/aiac.alls.v.5n.6p.39

Accepted: 27/09/2014

\begin{abstract}
Teaching is a stressful job and can lead to teachers' burnout. Teachers feel burned out when they experience high levels of emotional exhaustion and depersonalization but low levels of personal accomplishment (Maslach, 1999). A wealth of research is available on this subject but the findings are inconsistent. The present study surveyed the level of burnout among a randomly selected group of English language teachers $(n=315)$ in Malaysia. It also investigated whether these teachers' gender, age and marital status could significantly contribute to their burnout levels. Maslach's Burnout Inventory (Maslach \& Jackson, 1986) was used to collect the data. According to the results, the teachers suffered from significantly high levels of burnout in reference to their PA scores. In comparison with the male teachers, female teachers reported significantly higher levels of burnout considering their emotional exhaustion $(p=.008)$, depersonalization $(p=.002)$ and personal accomplishment $(p=.000)$. Additionally, older teachers $($ aged $\leq 40)$ were significantly more burned out than their younger colleagues (aged $\geq 30)$, regarding their depersonalization $(p=.001)$ and personal achievement $(p=.000)$ mean scores. Finally, married teachers indicated significantly higher levels of burnout compared with those who were not married. The study is expected to have useful implications for teachers, administrators, and researchers.
\end{abstract}

Keywords: burnout, emotional exhaustion, personal accomplishment, depersonalization, English language teachers

\section{Introduction}

Job burnout results from a stressful work environment. Teaching profession is associated with burnout because it is a stressful job (King \& Hegadoren, 2002; Kyriacou, 1989). Burnout is an important problem for teachers since it may affect their physical and psychological well-being negatively as well as the future of their job. It has a negative impact on the school system in addition to the undesirable consequences on the teachers themselves, but the biggest concern is its effect on the main target of the teaching profession; that is, the student. Teachers who are burned out may be less concerned about their students' needs and may lack the energy needed to handle their behaviour problems themselves (Evers, Tomic, \& Brouwers, 2004).

Teachers that are burned out may experience one or more of the three components of the burnout syndrome (Maslach, 1999; Maslach \& Schaufeli, 1993). Usually, burnout starts with the feeling of being emotionally overextended and drained by the intense contact with students, parents and colleagues (emotional exhaustion, referred to as EE onwards); then, it may lead the teacher to negative attitudes and cynical responses toward the students (depersonalization, referred to as DP in this paper). Finally, burnout can also result in teachers' negative evaluation of their performance and achievement in their job (personal accomplishment, referred to as PA onwards) (Maslach, 1999). Burnout produces physical and emotional exhaustion, detachment, and loss of job satisfaction (Kokkinos, Panayiotou, \& Davazoglou, 2005; Lau, Yuen, \& Chan, 2005; Sunbul, 2003). Various studies have investigated the importance of certain variables on burnout (Brewer \& Shapard, 2004; Cheek, Bradley, Parr, \& Lan, 2003; Goddard, O'Brien, \& Goddard, 2006; Gonzales, Brown, \& Slate, 2008; Kersaint, Lewis, Potter, \& Meisels, 2007; Kokkinos, et al., 2005; Lau, et al., 2005). This study sought to survey the burnout level of a group of school English language teachers in Malaysia. The study also examined whether English language teachers' gender, marital status, and age could significantly contribute to their burnout levels.

\subsection{Research questions and null hypotheses}

The following research questions were posed to address the objectives of this study:

1. Do English language teachers in Malaysian public schools indicate significantly high levels of burnout?

2. Does Malaysian public school teachers' gender significantly contribute to their burnout scores?

3. Does Malaysian public school teachers' age significantly contribute to their burnout scores? 
4. Does Malaysian public schools teachers' marital status significantly contribute to their burnout scores?

The following null hypotheses were postulated to test the statistical significance of the differences:

$\mathrm{H}_{\mathrm{O} 1}$. English language teachers in Malaysian public schools do not indicate significantly high levels of burnout.

$\mathrm{H}_{\mathrm{O} 2}$. Malaysian public school teachers' gender does not significantly contribute to their burnout levels.

$\mathrm{H}_{\mathrm{O} 3}$. Malaysian public school teachers' age does not significantly contribute to their burnout levels.

$\mathrm{H}_{\mathrm{O} 4}$. Malaysian public school teachers' marital status does not significantly contribute to their burnout levels.

\subsection{Literature review}

In this section the literature related to each research question is reviewed.

\subsubsection{Burnout among English language teachers}

There is little literature available on burnout among English language teachers. Most studies have focused on teacher burnout in relation with demographic variables, but few studies have focused on the level of subject specific teachers' burnout.

In a study of 184 English language teachers, Mukundan and Khandehroo (2010) found high levels of burnout among English teachers in the Malaysian public schools. They reported significantly high levels $(p=.001)$ of DP $(M=16.7$, $S D=6.12)$, EE $(M=31.30, S D=8.33)$ and reduced PA $(M=26.1, S D=8.47)$. In another study in Malaysia, Jamshidirad, Mukundan and Nimehchisalem (2012) reported low to moderate levels of EE and DP but moderate to high levels of PA in their small sample of 28 English language teachers.

\subsubsection{Gender and Burnout}

Studies on teachers' gender and burnout levels have indicated mixed results. While sometimes males have been observed to suffer from higher levels of burnout, at other times the opposite has been the case. There have also been findings showing no significant difference between males and females' burnout levels.

Some researchers have found that male teachers are more liable to burnout. For example, Ogus, Greenglass, and Burke (1990) reported that DP was more evident in males. In a meta-analysis of 183 studies, Purvanova and Muros (2010) found that DP was more marked in males though females showed slightly higher levels of EE. Studies on elementary and high school teachers have shown while females indicate higher levels of EE, their male colleagues report higher DP levels (Lackritz, 2004; Martin, 2000). Lackritz (2004) showed that female faculty members reported higher levels of EE, while males indicated higher levels of DP. Lackritz's results showed that gender did not contribute to any significant differences in PA levels. Similarly, Sunbul (2003) in a study of 297 high school teachers showed females scored lower on DP than did males.

On the contrary, other studies have indicated female teachers are prone to burnout more than male teachers. Women appear to be more burned out under a higher work-load (Lippel, 1999; Van Dick \& Wagner, 2001). Also in comparison with their male colleagues, women consider their work to be ordinary and unimportant (Lippel, 1999). Furthermore, higher levels of occupational stress and burnout have been observed in females as compared with males (Antoniou, Polychroni \& Vlachakis, (2006); Timms, Graham, \& Caltabiano, (2006).

Finally, other studies have discovered that gender causes no significant differences in levels of burnout (Evers, Brouwers, \& Tomic, 2002; Hastings \& Bham, 2003; Rosenblatt, 2001). Zhao and Bi (2003), based on a survey of 190 secondary school teachers in Mainland China, found no significant difference between male and female teachers in reference to their three dimensions of burnout. Holloman (1999) reported similar results in a study of 383 first year school teachers. Finally, in a study in Turkey, Kirilmaz, Celen, and Sarp (2003) found that gender did not have any significant effect on the burnout level of 43 primary school teachers.

\subsubsection{Age and Burnout}

Different studies have been conducted to explore the possible effect of age on burnout. These studies have shown inconsistent results. Some of these studies have shown that age is not a significant predictor of burnout whereas others have revealed age as an effective factor on burnout especially on EE. As it is the case in some studies, burnout is more common among younger individuals. On the contrary, other studies have indicated that older people indicate higher levels of burnout.

Sunbul (2003) found that age could influence different dimensions of burnout, and that young age was a significant predictor of a low level of PA. Overall Sunbul's results showed that the younger the subjects, the higher their burnout. Likewise, Antoniou et al. (2006) as well as Ozdemir (2007) found that younger teachers report higher burnout levels than older teachers. Gold (1985) as well as Schwab and Iwanicki (1982) carried out seminal research in which they surveyed the correlation between age and the three dimensions of burnout. The Maslach Burnout Inventory was used in both studies, which displayed that younger teachers showed higher levels of EE and DP. As Gold (1985) explains, younger teachers have not yet grasped the reality of the profession. The realization that the profession is not what is expected may become a source of frustration. This frustration felt by the teachers could elicit elevated levels of DP and EE (Gold, 1985). In a study of 437 female Malaysian teachers, it was found that the younger teachers were more burned out than their older colleagues (Mukundan \& Ahour, 2011). According to Maslach, Jackson, and Leiter (1996), age can significantly affect EE. Younger teachers, in their study, indicated higher levels of EE compared with the older ones. In a study in Macau, Luk, Chan, Cheong, and Ko (2010) explored the burnout of teachers in two schools. It was revealed 
that age was one of the demographic variables which could significantly contribute to burnout. Significant differences were observed in EE and DP. Younger teachers tended to show higher levels of burnout syndrome than their older colleagues.

Contrary to the findings of the aforementioned studies, Brewer and Shapard (2004)revealed that older teachers have higher burnout levels than younger ones. The study of Anderson and Iwanicki (1984) in the United States showed that age is not a significant predictor of burnout (as cited in (Grayson \& Alvarez, 2008). Similarly, Holloman (1999), in a study of 383 first-year school teachers, found that there were no significant differences between older and younger teachers' burnout levels. This was also the case in a study of primary school teachers in Turkey (Kirilmaz, et al., 2003). It was indicated that age did not have an effect on the burnout level of teachers. Croom (2003) found significantly small negative correlations between age and DP of agriculture teachers in three states in the southeast area of the United States. Croom did not find significant associations between teachers' age and their EE or PA. Finally, in a meta-analysis of 35 studies on K-12 teachers in the USA, Weng (2004) found that none of the demographic characteristics which had been investigated in the selected studies had very high predictive correlations with burnout.

\subsubsection{Marital status and Burnout}

Marital status has also been investigated as another demographic variable related to burnout in several studies, resulting in inconsistent findings. In most studies higher burnout was recorded for married teachers while in a few other studies the reverse was the case. In some other studies no significant difference was found.

Some researchers have found that single teachers are more prone to burnout than those who are married. For instance, in a number of studies, it was reported that singles have higher levels of burnout than married individuals regarding their EE and DP (De Heus \& Diekstra, (1999); Ozdemir, (2007); Yongxin et al,(2007). Similarly, it was found that single individuals (especially men) experience higher burnout level than those who are married and also singles are more prone to burnout than those who are divorced (Maslach, Schaufeli, \& Leiter, 2001). Also based on another study, it was reported that single individuals' EE and DP scores were significantly higher than those of married individuals whereas PA scores of married individuals were significantly higher (Sunter, Canbaz, Dabak, Oz, \& Peksen, 2006). In another study in Malaysia, Mukundan and Khandehroo (2009) confirmed that the pattern of burnout experienced by married female teachers is moderate, low and high for EE, DP, and PA, respectively while it is high, low and high for single female teachers. This implies that single teachers suffer more from burnout syndrome compared with married teachers. In the same line according to Goutas (2008), unmarried people tended to experience burnout more commonly than married people. Other studies also suggested that burnout is less common among married workers (Bataineh, 2005; Haddad, 1998; Russell, Altmaier, \& Van Velzen, 1987).

A few studies reported higher burnout levels for married teachers. For example, according to Ross, Altmaier, and Russell (1989) married workers experience greater EE than those who are not married and also Brunetti (2001) shares the view with Wong and Cheuk (1998) that married teachers who do not hire a babysitter suffer from burnout more than the teachers who have a babysitter.

Some research findings show no significant difference between the level of burnout of married and single teachers. A study by Louw, George, and Esterhuyse (2011)reported that marital status was one of the demographic factors which did not make significant differences in respondents' burnout levels. In a similar line, Holloman (1999) studied the relationship of personal and school related variables related to the level of burnout of 383 first-year school teachers' level. The results showed that there were no significant differences between the level of burnout of married and single teachers. In another study, Gavrilovici (2008) studied the burnout level of 178 teachers in primary, secondary, high schools, and special schools in Iasi County of Romania during the period 2007-2009. Based on the results, marital status did not prove any effect on any dimension of burnout. In a study conducted on 437 female teachers, Mukundan and Ahour (2011) found that age, years of teaching, the number of children and level of teaching were significant indicators, while marital status were not significantly related to their burnout. Likewise Gezer, Yenel and Sahan (2009) investigated if marital status has significant effect on the three dimensions of burnout of instructors. They reported that marital status did not affect any of the three dimensions of burnout.

\section{Method}

Quantitative method was used to collect and analyze the data. The respondents were 315 English language teachers randomly selected from different primary and secondary public schools located in the urban areas of Klang Valley, Malaysia. Two questionnaires were distributed among the respondents. The first was a demographic information form that was used to elicit information about socio-demographic characteristics of the respondents including their gender, age, and marital status. Table 1 provides an overview of demographic data related to the respondents' gender, age and marital status. Of all the 315 respondents, $189(60 \%)$ were females. As for their age, they were divided into two groups of younger ( 30 or less) and older ( 40 or more) teachers. The respondents who were aged 31 to 39 were disregarded in testing the contribution of age to burnout in order to make the gap between the two groups more distinct. A large proportion of the whole sample, $161(51.1 \%)$, was 30 years of age or younger while $63(20 \%)$ were 40 or older. Majority of the respondents, 227 (72.1\%), were married, and 88 (27.9\%) were not. 
Table1. Demographic characteristics of respondents

\begin{tabular}{llll}
\hline Demographics & & Frequency & Percentage $(\%)$ \\
\hline Gender & Male & 126 & 40 \\
& Female & 189 & 60 \\
\hline Age & 30 or younger & 161 & 51.1 \\
& $31-39$ & 91 & 28.9 \\
& 40 or older & 63 & 20 \\
\hline Marital status & Not married & 88 & 27.9 \\
& Married & 227 & 72.1 \\
\hline
\end{tabular}

The Maslach Burnout Inventory-Educators Survey (MBI- ES) was the second questionnaire (Maslach \& Jackson, 1986) that was used to elicit information on the teachers' burnout levels. The instrument evaluates three domains of burnout, including EE ( 9 items) measuring reduced energy and job enthusiasm, DP (5 items) measuring pessimism, lack of engagement and isolation from the students or dealing with students as inert, unfeeling objects, and lastly PA (8 items) evaluating feeling of competence and success about one's achievements. The MBI has a total of 22 items with a 7-point Likert-type scale ranging from 0-6 (where 0 signifies 'never' and 6 stands for 'every day'). For EE and DP domains, the higher the score, the higher the level of burnout. Conversely, the lower the PA score, the higher the burnout level. High internal consistency $(\mathrm{EE}=.90 ; \mathrm{DP}=.79 ; \mathrm{PA}=.71)$ and test-retest $(\mathrm{EE}=.82 ; \mathrm{DP}=.60 ; \mathrm{PA}=.80)$ Cronbach's Alpha reliability values have been reported for this scale (Maslach \& Jackson, 1986).

SPSS (Version 20.0) was used to analyse the data. The independent variables were gender, age and marital status while the three burnout components (i.e., EE, DP, and PA) were the dependent variables of the study. The sum of each component of burnout was computed. Descriptive and inferential statistics, including frequency, percentage, means, standard deviations, and t-test were used in the analysis. One-sample t-test was used to test the first null hypothesis, and independent samples t-test was used to test the other hypotheses.

\section{Results and Discussion}

The research questions focused on the teachers' level of burnout (the first research question) as well as the contribution of their gender (the second research question), age (the third research question), and marital status (the fourth research question) to their burnout levels. This section reports and discusses the results of data analysis for each research question.

\subsection{Level of burnout}

The first research question concerned the level of burnout among the Malaysian English language teachers. The cut-off points for each component of burnout were determined following Rosenberg and Pace (2006). They suggest EE and DP scores exceeding 27 and13, respectively, and PA scores below 31 be considered indicators of high levels of burnout. In order to answer the first research questions, the means and standard deviations of each of the burnout components were calculated (Table 2).

Table 2. Descriptive statistics results for burnout components $(n=315)$

\begin{tabular}{lrrr}
\hline Burnout component & Mean & Std. Deviation & Test value \\
\hline Emotional exhaustion & 24.46 & 9.23 & 27 \\
Depersonalization & 10.69 & 5.58 & 13 \\
Personal accomplishment & 26.29 & 8.03 & 31 \\
\hline
\end{tabular}

As the results showed, the respondents' mean scores for EE $(M=24.46, S D=9.23)$ and DP $(M=10.69, S D=5.58)$ turned out to be below the cut-off points of 27 and 13, respectively. This would suggest that the respondents did not suffer from high levels of burnout in reference to their EE and DP means scores. It was, however, found that the respondents' PA mean scores $(M=28.37, S D=8.04)$ were below the cut-off point $(31)$. A low level of PA can contribute to burnout; therefore, it could be concluded that in reference to their PA, the respondents suffered from high levels of burnout. In order to test the significance of the difference between the burnout component mean scores and the test values, or the cut-off points, one-sample t-test was used.

Table 3. Significance of teachers' burnout $(n=315)$

\begin{tabular}{|c|c|c|c|c|c|c|}
\hline \multirow{2}{*}{ Burnout component } & \multirow{2}{*}{$\begin{array}{c}\text { Test } \\
\text { value }\end{array}$} & \multirow{2}{*}{$\mathrm{t}$} & \multirow{2}{*}{ df } & \multirow{2}{*}{$\begin{array}{l}\text { Sig. (2- } \\
\text { tailed) }\end{array}$} & \multicolumn{2}{|c|}{$\begin{array}{l}\text { 95\% Confidence Interval of the } \\
\text { Difference }\end{array}$} \\
\hline & & & & & Lower & Upper \\
\hline $\begin{array}{l}\text { Emotional } \\
\text { exhaustion }\end{array}$ & 27 & 4.88 & 314 & .000 & -3.56 & -1.52 \\
\hline Depersonalization & 13 & 7.34 & 314 & .000 & -2.93 & -1.69 \\
\hline $\begin{array}{l}\text { Personal } \\
\text { accomplishment }\end{array}$ & 31 & 10.41 & 314 & .000 & -5.60 & -3.82 \\
\hline
\end{tabular}


Table 3 summarizes the results of the one-sample t-test, according to which the significant values for $\mathrm{EE}, \mathrm{DP}$, and $\mathrm{PA}(p$ $=.000$ ) were all smaller than $\alpha$ at .05 level of significance. As it was discussed in the descriptive statistics results (Table 2 ), the mean scores for EE and DP were below the cut-off points. It can be concluded that the respondents did not suffer from high levels of burnout in reference to their EE and DP scores. Medium effect sizes were reported for EE $(r=.266)$ and DP $(\mathrm{r}=.383)$. Inconsistent with these findings were the results obtained for PA, which showed the respondents had significantly lower PA mean scores than the test value. This would imply that the respondents suffered from significantly high levels of burnout regarding their significantly low PA scores. The difference indicated a large effect size $(\mathrm{r}=.506)$.

In a similar study conducted in Malaysia, the level of PA had also turned out to be significantly low (Mukundan \& Khandehroo, 2010). In contrast, Mukundan and Khandehroo (2010) reported significantly high levels of DP and EE among Malaysian public school English language teachers. One probable reason for this inconsistency could be the varying levels of workload of the teachers in of the two studies. The teachers in Mukundan and Khandehroo's study had to be engaged as 'critical friends' in the English for the Teaching of Mathematics and Science (ETeMS) Buddy System (Yeow, 2003). Since Mehematics and Science were being taugh in English at the time, English language teachers had to assist Math and Scince teachers in designing tests and solving their language problems. The ETeMS program continued only until 2012 in Malaysian public schools, and it was not being implemented anymore during this study, which would relieve our sample from the additional workload in Mukundan and Khandehroo's study. Therefore, the reason why the respondents in this study did not indicate high levels of EE or DP could be attributed to their lower workload, which can significantly and negatively contribute to teachers' burnout (Male \& May, 2009).

\subsection{Gender and Burnout}

The second research question concerned the effect of English language teachers' gender on their burnout levels. According to the results (Table 4), lower levels of EE $(M=22.78, S D=10.20)$ and DP $(M=9.52, S D=5.55)$ but higher levels of PA $(M=28.37, S D=8.04)$ were observed in male teachers.

Table 4. Gender and burnout

\begin{tabular}{|c|c|c|c|c|c|c|c|c|c|}
\hline & & & & & \multirow[t]{2}{*}{$\mathrm{t}$} & \multirow[t]{2}{*}{ df } & \multirow[t]{2}{*}{$\begin{array}{l}\text { Sig. (2- } \\
\text { tailed) }\end{array}$} & \multicolumn{2}{|c|}{$\begin{array}{l}95 \% \text { Confidence } \\
\text { Interval of the } \\
\text { Difference }\end{array}$} \\
\hline & & & & & & & & Lower & Upper \\
\hline \multirow{2}{*}{$\begin{array}{l}\text { Emotional } \\
\text { exhaustion }\end{array}$} & Male & 126 & 22.78 & 10.17 & \multirow{2}{*}{-2.67} & \multirow{2}{*}{313} & \multirow{2}{*}{.008} & \multirow{2}{*}{-4.87} & \multirow{2}{*}{-.74} \\
\hline & Female & 189 & 25.58 & 8.38 & & & & & \\
\hline \multirow[t]{2}{*}{ Depersonalization } & Male & 126 & 9.52 & 5.55 & \multirow{2}{*}{-3.08} & \multirow{2}{*}{313} & \multirow{2}{*}{.002} & \multirow{2}{*}{-3.19} & \multirow{2}{*}{-.70} \\
\hline & Female & 189 & 11.47 & 5.47 & & & & & \\
\hline \multirow{2}{*}{$\begin{array}{l}\text { Personal } \\
\text { accomplishment }\end{array}$} & Male & 126 & 28.37 & 8.04 & \multirow{2}{*}{3.84} & \multirow{2}{*}{313} & \multirow{2}{*}{.000} & \multirow{2}{*}{1.69} & \multirow{2}{*}{5.25} \\
\hline & Female & 189 & 24.90 & 7.73 & & & & & \\
\hline
\end{tabular}

These results suggest that the female teachers in this study were more prone to burnout. As it is shown in Table 4, the significant values for EE, DP, and PA, $(p=.008, .002$, and .000 , respectively) were all smaller than $\alpha(.05)$, indicating that the second null hypothesis is rejected. Therefore, it can be concluded that there is a significant difference in EE, DP, and PA scores between male and female teachers. Female teachers indicated higher levels of EE and DP but lower levels of PA with small to medium effect sizes of.149, .171, and .212 for EE, DP, and PA, respectively. These findings were consistent with the studies carried out by Antoniou et al. (2006), Lippel (1999), Timms, et al. (2006) and Van Dick and Wagner (2001) who also found that female teachers are more prone to burnout than male colleagues.

\subsection{Age and Burnout}

The third research question was related to the effect of English language teachers' age on their burnout levels. The respondents were divided into two groups of younger (30 or below) and older (40 or above) teachers. Based on the independent samples t-test results (Table 5), slightly higher total EE scores $(M=24.43, S D=9.81)$ were reported for younger teachers as compared with the older group $(M=23.53, S D=6.22)$, but this difference was statistically insignificant $(p=.412)$. In contrast, the older group's total DP score $(M=11.92, S D=3.64)$ was higher than the younger group's $(M=9.81, S D=5.74)$, and this difference was significant $(p=.001)$. Finally, in reference to their PA scores, the older group indicated lower mean scores $(M=24.70, S D=6.40)$ in comparison with the younger group $(M=$ $28.35, S D=7.61)$, and the difference was statistically significant $(p=.000)$. 


\begin{tabular}{|c|c|c|c|c|c|c|c|c|c|}
\hline \multirow[t]{2}{*}{$\begin{array}{l}\text { Burnout } \\
\text { component }\end{array}$} & \multirow[t]{2}{*}{ Age } & \multirow[t]{2}{*}{$\mathrm{N}$} & \multirow[t]{2}{*}{ Mean } & \multirow[t]{2}{*}{ SD } & \multirow[t]{2}{*}{$\mathrm{t}$} & \multirow[t]{2}{*}{ df } & \multirow[t]{2}{*}{$\begin{array}{l}\text { Sig. (2- } \\
\text { tailed) }\end{array}$} & \multicolumn{2}{|c|}{$\begin{array}{l}95 \% \text { Confidence } \\
\text { Interval of the } \\
\text { Difference }\end{array}$} \\
\hline & & & & & & & & Lower & Upper \\
\hline \multirow{2}{*}{$\begin{array}{l}\text { Emotional } \\
\text { exhaustion }\end{array}$} & $\geq 30$ & 161 & 24.43 & 9.81 & \multirow{2}{*}{.822} & \multirow{2}{*}{176.66} & \multirow{2}{*}{.412} & \multirow{2}{*}{$-.1 .27$} & \multirow{2}{*}{3.07} \\
\hline & $40 \leq$ & 63 & 23.52 & 6.22 & & & & & \\
\hline \multirow[t]{2}{*}{ Depersonalization } & $\geq 30$ & 161 & 9.81 & 5.74 & \multirow{2}{*}{-3.27} & \multirow{2}{*}{176.58} & \multirow{2}{*}{.001} & \multirow{2}{*}{-3.38} & \multirow{2}{*}{-.84} \\
\hline & $40 \leq$ & 63 & 11.92 & 3.64 & & & & & \\
\hline \multirow{2}{*}{$\begin{array}{l}\text { Personal } \\
\text { accomplishment }\end{array}$} & $\geq 30$ & 161 & 28.35 & 7.61 & \multirow{2}{*}{3.64} & \multirow{2}{*}{133.66} & \multirow{2}{*}{.000} & \multirow{2}{*}{1.67} & \multirow{2}{*}{5.64} \\
\hline & $40 \leq$ & 63 & 24.70 & 6.40 & & & & & \\
\hline
\end{tabular}

These results showed that the younger teachers indicated lower levels of DP and higher levels of PA with medium effect sizes of $r=.239$ and .3 . This means that the teachers in the older group in this research felt more burned out as compared with the younger group. One possible culprit for burnout among older teachers could be routinization which may emerge after years of doing the same job. Doing the same responsibilities over a long period can lead to boredom and reduce the excitement and motivation that are commonly experienced by younger teachers. Therefore, older teachers may experience more burned out because they have repeatedly carried out similar duties for many years. The result was consistent with that of Brewer and Shapard (2004) but it did not support previous research findings by Antoniou et al. (2006), Mukundan and Ahour (2011), Ozdemir (2007) or Sunbul (2003) who reported younger teachers tended to experience greater burnout levels than older teachers.

\subsection{Marital status and Burnout}

The final research question focused on the effect of English language teachers' marital status on their burnout levels. According to the results (Table 6$)$, higher levels of EE $(M=24.71, S D=8.91)$ and DP $(M=11.15, S D=5.40)$ but lower levels of PA $(M=25.22, S D=8.16)$ were observed in married teachers.

Table 6. Marital status and burnout

\begin{tabular}{|c|c|c|c|c|c|c|c|c|c|}
\hline \multirow[t]{2}{*}{$\begin{array}{c}\text { Burnout } \\
\text { component }\end{array}$} & \multirow[t]{2}{*}{$\begin{array}{l}\text { Marital } \\
\text { status }\end{array}$} & \multirow[t]{2}{*}{$\mathrm{N}$} & \multirow[t]{2}{*}{ Mean } & \multirow[t]{2}{*}{$\mathrm{SD}$} & \multirow[t]{2}{*}{$\mathrm{t}$} & \multirow[t]{2}{*}{ df } & \multirow[t]{2}{*}{$\begin{array}{l}\text { Sig. (2- } \\
\text { tailed) }\end{array}$} & \multicolumn{2}{|c|}{$\begin{array}{l}95 \% \text { Confidence } \\
\text { Interval of the } \\
\text { Difference }\end{array}$} \\
\hline & & & & & & & & Lower & Upper \\
\hline $\begin{array}{l}\text { Emotional } \\
\text { exhaustion }\end{array}$ & $\begin{array}{c}\text { Not married } \\
\text { Married }\end{array}$ & $\begin{array}{c}88 \\
227\end{array}$ & $\begin{array}{l}23.79 \\
24.72\end{array}$ & $\begin{array}{l}10.01 \\
8.92\end{array}$ & -.80 & 313 & .427 & -3.20 & 1.36 \\
\hline Depersonalization & $\begin{array}{c}\text { Not married } \\
\text { Married }\end{array}$ & $\begin{array}{c}88 \\
227\end{array}$ & $\begin{array}{c}9.50 \\
11.15\end{array}$ & $\begin{array}{l}5.87 \\
5.40\end{array}$ & -2.38 & 313 & .018 & -3.02 & -.29 \\
\hline $\begin{array}{l}\text { Personal } \\
\text { accomplishment }\end{array}$ & $\begin{array}{l}\text { Not married } \\
\text { Married }\end{array}$ & $\begin{array}{c}88 \\
227\end{array}$ & $\begin{array}{l}29.06 \\
25.22\end{array}$ & $\begin{array}{l}6.99 \\
8.16\end{array}$ & 3.89 & 313 & .000 & 1.89 & 5.78 \\
\hline
\end{tabular}

As it is shown in Table 6 , the significant value for EE $(p=.427)$ was bigger than alpha (.05). Therefore, it can be concluded that there is no significant difference in EE scores of not married and married teachers. Since the significant value for DP, and PA ( $p=.018$, and .000 , respectively) were smaller than $\alpha(.05)$, it can be concluded that there is a significant difference in DP and PA scores of not married and married teachers. These results suggest that the married teachers felt more burned out regarding their DP with a medium effect size $(r=.215)$ whereas teachers who were married were more burned out in reference to their PA indicating a small effect size $(r=.133)$. The reason could be the higher burden of responsibilities normally faced by married teachers. This seems particularly true about Malaysian married women, who are expected to do the housework even when they are employed. These findings contradict the results of De Heus and Diekstra (1999) as well as Yongxin et al. (2007), while they are quite consistent with the results of Sunter et al. (2006). Sunter et al. (2006), who showed that single individuals' EE and DP scores and married individuals' PA scores were significantly higher. In this regard, Maslach et al. (2001) found that married employees with fewer children are more prone to burnout, whilst single employees are in the group of greater burnout risk than 
divorced employees. However, Bauer et al. (2006) provide empirical evidence that burnout is significantly higher among employees with marital problems such as divorcees and widowers.

\section{Conclusion}

The present study sought to investigate the level of burnout among Malaysian English language teachers as well as the contribution of these teachers' gender, age, and marital status to their burnout levels. Burnout definitely has contradictory personal and institutional outcomes (Cordes \& Dougherty, 1993; Maslach, et al., 2001). It may affect people in any service profession but teachers are more prone to burnout because the job is claimed to be very challenging.

As the comparison between our results and previous research (Mukundan \& Khandehroo, 2010) findings implied, exessive workload can rsult in English language teachers' burnout. Therefore, educational policy makers should consider the extra workload that additional programs may add to teachers' busy schedules and result in their high burnout levels. Another matter that was raised in the discussion of results was the issue of routinization that can be avoided by creating a dynamic environment at schools. Relevant professional development activities can be mentioned as one possible way to avoid routinzation. The findings of this study clearly show that measures need to be taken to increase language teachers' positive feelings towards their job. Particular attention needs to be paid to older female English language teachers.

Obviously, more study of teacher burnout is necessary. The following recommendations can be suggested for further research. As stated earlier, there are very few studies of subject specific teachers' burnout, and the few studies conducted in this area indicated contradictory results. A study of the burnout level of English language teachers as compared with that of teachers who teach other subjects may lead to interesting findings. This study focussed on the direct influence of respondents' demographic variables on their burnout levels. There could be certain mediating variables, like teachers' self-efficacy or emotional intelligence that could have affected the results. Further study in this respect can lead to interesting theoretical implications.

\section{References}

Anderson, M. B. G., \& Iwanicki, E. F. (1984). Teacher motivation and its relationship to burnout. Educational Administration Quarterly, 20(2), 109-132.

Antoniou, A. S., Polychroni, F., \& Vlachakis, A. N. (2006). Gender and age differences in occupational stress and professional burnout between primary and high-school teachers in Greece. Journal of Managerial Psychology, 21(7), 682-690.

Bataineh, O. (2005). Burnout among resource room teachers in northern Jordan. Jordan Journal of Educational Sciences, 1(1), 105-113.

Bauer, J., Stamm, A., Virnich, K., Wissing, K., Muller, U., Wirsching, M., et al. (2006). Correlation between burnout syndrome and psychological and psychosomatic symptoms among teachers. International Archives of Occupational and Environmental Health, 79(3), 199-204.

Brewer, E. W., \& Shapard, L. (2004). Employee burnout: A meta-analysis of the relationship between age or years of experience. Human Resource Development Review, 3(2), 102-123.

Brunetti, G. J. (2001). among Long-Term High School Teachers. Teacher Education Quarterly.

Cheek, J. R., Bradley, L. J., Parr, G., \& Lan, W. (2003). Using music therapy techniques to treat teacher burnout. Journal of Mental Health Counseling, 25(3), 204-217.

Cohen, J. (1988). Statistical power analysis for the behavioral sciences ( , 2nd Edition. ed.): Hillsdale: Lawrence Erlbaum.

Cordes, C. L., \& Dougherty, T. W. (1993). A review and an integration of research on job burnout. Academy of Management Review, 621-656.

Croom, D. B. (2003). Teacher burnout in agricultural education. Journal of Agricultural Education, 44(2), 1-13.

De Heus, P., \& Diekstra, R. F. W. (1999). Do teachers burn out more easily? A comparison of teachers with other social professions on work stress and burnout symptoms.

Evers, W. J. G., Brouwers, A., \& Tomic, W. (2002). Burnout and self-efficacy: A study on teachers' beliefs when implementing an innovative educational system in the Netherlands. British Journal of Educational Psychology, 72(2), 227-243.

Evers, W. J. G., Tomic, W., \& Brouwers, A. (2004). Burnout among teachers. School Psychology International, 25(2), 131-148.

Gavrilovici, L. O. (2008). Romanian teachers' burnout and psychological and professional difficulties. The Internet: http://holon. ladipu. com/resources/15//Romanian\% 20teachers'\% 20burnout\% 20and, 20.

Gezer, E., Yenel, F., \& Sahan, H. (2009). Öğretim elemanlarının tükenmişlik düzeyleri ile sosyodemografik değişkenleri arasındaki ilişki (Relationship between burnout levels and socio-demographic variables of academicians). Uluslararasi Sosyal Arastirmalar Dergisi (The Journal of International Social Research, 2, 6. 
Goddard, R., O'Brien, P., \& Goddard, M. (2006). Work environment predictors of beginning teacher burnout. British Educational Research Journal, 32(6), 857-874.

Gold, Y. (1985). Does teacher burnout begin with student teaching. Education.

Gonzales, L., Brown, M. S., \& Slate, J. R. (2008). Teachers who left the teaching profession: A qualitative understanding. The Qualitative Report, 13(1), 1-11.

Goutas, L. J. (2008). Burnout. The Journal of the European Medical Writers Association, 17(3), 135-138.

Grayson, J. L., \& Alvarez, H. K. (2008). School climate factors relating to teacher burnout: A mediator model. Teaching and Teacher Education, 24(5), 1349-1363.

Haddad, A. (1998). Sources of social support among school counsellors in Jordan and its relationship to burnout. International Journal for the Advancement of Counselling, 20(2), 113-121.

Hastings, R. P., \& Bham, M. S. (2003). The relationship between student behaviour patterns and teacher burnout. School Psychology International, 24(1), 115-127.

Holloman, H. L. (1999). Factors related to burnout in first-year teachers in South Carolina.

Jamshidirad, M., Mukundan, J., \& Nimehchisalem, V. (2012). Language Teachers' Burnout and Gender. International Journal of Applied Linguistics and English Literature 1(4), 46-52. doi: 10.7575/ijalel.v.7571n.7574p.7574

Kersaint, G., Lewis, J., Potter, R., \& Meisels, G. (2007). Why teachers leave: Factors that influence retention and resignation. Teaching and Teacher Education, 23(6), 775-794.

King, S. L., \& Hegadoren, K. M. (2002). Stress hormones: how do they measure up? Biological Research for Nursing, 4(2), 92-103.

Kirilmaz, A. Y., Celen, U., \& Sarp, N. (2003). Ilkögretimde Çalisan bir Ögretmen Grubunda "Tükenmislik Durumu” Arastirmasi. Ilkögretim Online, 2(1), 2-9.

Kokkinos, C. M., Panayiotou, G., \& Davazoglou, A. M. (2005). Correlates of teacher appraisals of student behaviors. Psychology in the Schools, 42(1), 79-89.

Kyriacou, C. (1989). The nature and prevalence of teacher stress. Teaching and Stress, 26-35.

Lackritz, J. R. (2004). Exploring burnout among university faculty: incidence, performance, and demographic issues. Teaching and Teacher Education, 20(7), 713-729.

Lau, P., Yuen, M., \& Chan, R. (2005). Do demographic characteristics make a difference to burnout among Hong Kong secondary school teachers? Quality-of-Life Research in Chinese, Western and Global Contexts, 491-516.

Lippel, K. (1999). Workers' Compensation and Stress. International Journal of Law and Psychiatry, 22(1), 79-89.

Louw, D., George, E., \& Esterhuyse, K. (2011). Burnout amongst urban secondary school teachers in Namibia. $S A$ Journal of Industrial Psychology, 37(1), doi:10.4102/sajip.v4137i4101.1008.

Luk, A. L., Chan, B. P. S., Cheong, S. W., \& Ko, S. K. K. (2010). An exploration of the burnout situation on teachers in two schools in Macau. Social Indicators Research, 95(3), 489-502.

Male, D., \& May, D. (2009). Burnout and workload in teachers of children with severe learning difficulties. British Journal of Learning Disabilities, 25(3), 117-121.

Martin, J. (2000). Hidden gendered assumptions in mainstream organizational theory and research. Journal of Management Inquiry, 9(2), 207-216.

Maslach, C. (1999). 12. Progress in Understanding Teacher Burnout. Understanding and Preventing Teacher Burnout: A sourcebook of International Research and Practice, 211.

Maslach, C., \& Jackson, S. E. (1986). MBI: Maslach Burnout Inventory; manual research edition. University of California, Palo Alto, CA.

Maslach, C., Jackson, S. E., \& Leiter, M. P. (1996). Maslach burnout inventory manual . Mountain View, CA: CPP. Inc. [Links].

Maslach, C., \& Schaufeli, W. B. (1993). Historical and conceptual development of burnout. Professional Burnout: Recent Developments in Theory and Research, 1-16.

Maslach, C., Schaufeli, W. B., \& Leiter, M. P. (2001). Job burnout. Annual review of psychology, 52(1), $397-422$.

Mukundan, J., \& Ahour, T. (2011). Burnout Among Female Teachers In Malaysia. Journal of International Education Research (JIER), 7(3), 25-38.

Mukundan, J., \& Khandehroo, K. (2009). Burnout in relation to gender, educational attainment, and experience among Malaysian ELT practitioners. The Journal of Human Resource and Adult Learning, 5(2), 93-98.

Mukundan, J., \& Khandehroo, K. (2010). Burnout among English language teachers in Malaysia. Contemporary Issues in Education Research (CIER), 3(1), 71-76.

Ogus, E. D., Greenglass, E. R., \& Burke, R. J. (1990). Gender-role differences, work stress and depersonalization. Journal of Social Behavior \& Personality, 5, 387-398. 
Ozdemir, Y. (2007). The role of classroom management efficacy in predicting teacher burnout. Int J Soc Sci, 2(4).

Purvanova, R. K., \& Muros, J. P. (2010). Gender differences in burnout: A meta-analysis. Journal of Vocational Behavior, 77(2), 168-185.

Rosenberg, T., \& Pace, M. (2006). Burnout among mental health professionals: Special considerations for the marriage and family therapist. Journal of Marital and Family Therapy, 32(1), 87-99.

Rosenblatt, Z. (2001). Teachers' multiple roles and skill flexibility: Effects on work attitudes. Educational Administration Quarterly, 37(5), 684-708.

Ross, R. R., Altmaier, E. M., \& Russell, D. W. (1989). Job stress, social support, and burnout among counseling center staff. Journal of Counseling Psychology, 36(4), 464.

Russell, D. W., Altmaier, E., \& Van Velzen, D. (1987). Job-related stress, social support, and burnout among classroom teachers. Journal of Applied Psychology, 72(2), 269.

Saari, L. M., \& Judge, T. A. (2004). Employee attitudes and job satisfaction. Human Resource Management, 43(4), 395-407.

Schwab, R. L., \& Iwanicki, E. F. (1982). Perceived role conflict, role ambiguity, and teacher burnout. Educational Administration Quarterly, 18(1), 60-74.

Sunbul, A. M. (2003). An analysis of relations among locus of control, burnout and job satisfaction in Turkish high school teachers. Australian Journal of Education-Hawthorn-, 47(1), 58-72.

Sunter, A., Canbaz, S., Dabak, S., Oz, H., \& Peksen, Y. (2006). "Pratisyen Hekimlerde Tükenmişlik, İşe Bağlı Gerginlik ve İş Doyumu Düzeyleri,”. Genel Tip Dergisi, 16(1), 9-14.

Timms, C., Graham, D., \& Caltabiano, M. (2006). Gender implication of perceptions of trustworthiness of school administration and teacher burnout/job stress. Australian Journal of Social Issues, The, 41(3), 343.

Van Dick, R., \& Wagner, U. (2001). Stress and strain in teaching: A structural equation approach. British Journal of Educational Psychology, 71(2), 243-259.

Weng, C. H. (2004). Meta-analysis of teacher burnout in public schools in the United States. University of South Dakota.

Willimon, W. H. (1989). Clergy and laity burnout. US: Abingdon Press.

Wong, K. S., \& Cheuk, W. H. (1998). Beginning Teachers. Chinese University Education Journal, 26(1), 117-129.

Yeow, P. W. (2003). How critical are critical friends? An initial study on the implementation of the buddy support system. . Paper presented at the Paper presented at the ETeMS Conference:Managing curricular change. Pearl International Hotel 2 - 4 December

Yongxin, L., Xuan, Y., \& Jiliang, S. (2007). The Relationship between Teachers' Sense of Teaching Efficacy and Job Burnout. Psychological Science-Shanghi-, 30(4), 952.

Zhao, Y., \& Bi, C. (2003). Job burnout and the factors related to it among middle school teachers. Psychological Development and Education, 1, 80-84. 